\title{
Components of Total Factor Productivity Growth of the 2-Digit Manufacturing Industries in Karnataka: A Stochastic Frontier Approach
}

Prasanta Kumar Roy*, Sebak Kumar Jana† and Devkumar Nayek $\ddagger$

\section{Abstract}

The study estimates the sources of total factor productivity growth (TFPG) of the 2-digit manufacturing industries in Karnataka during the period from 1981-82 to 2010-11, during the entire study period, during the pre \& post reform period (1981-82 to 1990-91 and 1991-92 to 2010-11) and also during two different decades of the post-reform period, i.e., during 1991-92 to 2000-01 and 2001-02 to 2010-11 using stochastic frontier approach. Technological progress is found to be the major driving force of TFPG and the decline in TFPG of the state's manufacturing industries during the post-reform period is mainly accounted for by the decline in technological progress (TP) of the same during that period.

Keywords: Stochastic Frontier Production Function, Total Factor Productivity Growth

\section{Introduction}

Karnataka is one of the most progressive and industrialized states in the country and is a leading state in driving India's economic

\footnotetext{
* Midnapore College (Autonomous), West Bengal; prasanta.agnik@gmail.com

† Vidyasagar University, West Bengal; sebakjana@yahoo.co.in

‡ Midnapore College (Autonomous), West Bengal;

dev.kumar.nayek1987@gmail.com
} 
growth. However, economic growth and fast development of any state depend certainly on its industrial growth. Equally significant is the industrial productivity. Productivity generally means total factor productivity (TFP) that is the ratio of total output and total factor inputs. Recent studies on total factor productivity growth (TFPG) by means of stochastic production frontier show that TFPG consists of various components.

The stochastic frontier model assumes that firms do not fully utilize existing resources and technology because of various non-price and organizational factors that may lead to inevitable technical inefficiencies in production (Mandal \& Madheswaran, 2009). The model was pioneered by Aigner et al. (1977) and Meeusenand van den Broeck (1977) that decomposed TFP growth into two components: technological progress (TP) and changes in technical efficiency (TE). The model was extended by Pitt and Lee (1981), Schmidt and Sickles (1984), Kumbhakar (1990) and Battese and Coelli $(1992,1995)$ to allow for panel data estimation, in which technical efficiency and technological progress vary over time and across production units. A large number of empirical studies contributed to identifying the sources of TFP growth by focusing on its decompositions; representative studies are Nishimizu and Page (1982), Kumbhakar (1990), Fecher and Perelman (1992), Domazlicky and Weber (1998), to mention only a few. Some studies have extended their analysis to deal with issues such as scale effects and allocative efficiency effects. By applying a flexible translog stochastic function, Kumbhakar and Lovell (2000), Kim and Han (2001) and Sharma et al. (2007) decompose TFP growth into four components: technological progress, changes in technical efficiency, economic scale effect and allocation efficiency effect (Hamit Haggar, 2009).

The objective of the study is to decompose the TFP growth of Karnataka's manufacturing industries using the stochastic frontier approach. Having a detailed panel data set of the 2-digit manufacturing industries in Karnataka during the period from 1981-82 to 2010-11, we break down the TFP growth of the state's manufacturing industries into the aforementioned four components. The 2-digit industries of Karnataka considered in the study are: (1) manufacturer of food, beverages and tobacco 
products (20-22), (2) manufacturer of textile and textile products $(23+24+25+26)$, (3) manufacturer of wood and wood products; furniture and fixtures (27), (4) manufacturer of paper and paper products (28), (5) manufacturer of chemicals and chemical products (30), (6) manufacturer of rubber, petroleum and coal products (31), (7) manufacturer of non-metallic mineral products (32), (8) manufacturer of basic metals and alloys industries (33), (9) manufacturer of metal products and machinery equipments (3436), (10) manufacturer of transport equipments (37) and total manufacturing industry of the state. Decomposing the TFP growth of Karnataka's manufacturing industries into technological progress and efficiency changes are important to better understand whether gains in industries' productivity levels are achieved through the efficient use of inputs or through technological progress (Haggar, 2009). From this perspective, the authors argue that the decomposition carried out in this study may be very helpful to elicit the correct diagnosis of Karnataka's manufacturing productivity problem if any and develop effective policies to reverse the situation, and thereby reduce Karnataka's lagging productivity gap.

The rest of the paper is organized as follows. The next section outlines the stochastic frontier production function and methodology employed to decompose the TFP growth of Karnataka's manufacturing industries (Hamit Haggar, 2009). Following this, data and variable definitions are presented. Section 4 presents the empirical results and the final section contains some concluding remarks.

\section{Methodology}

Aigner, Lovell, and Schmidt (1977) and Meeusen, and van den Broeck (1977) independently proposed the stochastic frontier production function defined by

$\mathrm{y}_{\mathrm{it}}=\mathrm{f}\left(\mathrm{x}_{\mathrm{it}}, \beta, \mathrm{t}\right) \exp \left(\mathrm{v}_{\mathrm{it}}-\mathrm{u}_{\mathrm{it}}\right)$

where $y_{i t}$ is the maximum possible output produced by $i^{\text {th }}$ industry $(i=1,2, \ldots \ldots ., N)$ in the $t^{\text {th }}$ period $(t=1, \ldots \ldots \ldots, T)$; with $f($.$) being the$ production frontier; $x_{i t}$ being the input vector used by $i^{\text {th }}$ industry; $\beta$ being the vector of technology parameter; $t$ being the time trend 
index that serves as proxy for technological change; and $\mathrm{u}_{\mathrm{it}} \geq 0$ is the output oriented technical inefficiency. The random error, $\mathrm{v}_{\mathrm{it}}$, accounts for measurement error and all other random factors outside the control of the industry, such as weather, strikes, luck, etc., that are likely to affect its maximum possible output, together with the combined effects of unspecified input variables in the production function. It can be noted from equation (1) that technical inefficiency in equation (1) varies over time. The production frontier, $\mathrm{f}($.$) , is totally differentiated with respect to$ time to get

$\dot{y}_{\mathrm{it}}=\partial \operatorname{lnf}\left(\mathrm{x}_{\mathrm{it}}, \beta, \mathrm{t}\right) / \partial \mathrm{t}+\sum_{j} \partial \operatorname{lnf}\left(\mathrm{x}_{\mathrm{it}}, \beta, \mathrm{t}\right) / \partial \mathrm{x}_{\mathrm{jt}} \mathrm{d} \mathrm{x}_{\mathrm{jt}} / \mathrm{dt}-\mathrm{du} \mathrm{u}_{\mathrm{it}} / \mathrm{dt}$

The first and second terms on the right-hand side of equation (2) measure the change in frontier output caused by TP and by a change in input use respectively. From the output elasticity of input j, $\varepsilon_{j}=\partial \operatorname{lnf}\left(x_{\mathrm{it}}, \beta, \mathrm{t}\right) / \partial \ln \mathrm{x}_{\mathrm{j} \mathrm{t}}$, the second term can be expressed as $\sum_{j} \varepsilon_{j} \dot{\mathrm{x}}_{\mathrm{j} t}$, where a dot over a variable indicates its rate of change. Thus, equation (2) can be written as

$\dot{\mathrm{y}}_{\mathrm{it}}=\mathrm{TP}_{\mathrm{it}}+\sum_{j} \varepsilon_{j} \dot{\mathrm{x}}_{\mathrm{jt}} \mathrm{du} \mathrm{u}_{\mathrm{it}} / \mathrm{dt}$

The overall output growth is not only affected by TP and changes in input use, but also by changes in technical inefficiency. TP is positive (negative) if the exogenous technological change shifts the production frontier upward (downward), for a given level of inputs. If $\mathrm{du}_{\mathrm{it}} / \mathrm{dt}$ is negative (positive), TE improves (deteriorates) over time (Mandal \& Madheswaran, 2009), and $\mathrm{du}_{\mathrm{it}} / \mathrm{dt}$ can be interpreted as the rate at which an inefficient producer catches up with the production frontier.

To examine the effect of TP and a change in efficiency on TFP growth $(T F P), T F P$ is defined as output growth unexplained by input growth:

$\operatorname{TFP}=\dot{\mathrm{y}}_{\mathrm{it}} \sum_{j} \mathrm{~S}_{\mathrm{j}} \dot{\mathrm{x}}_{\mathrm{jt}}$ 
where $S_{j}$ denotes observed expenditure share of input $x$.

By substituting equation (3) into equation (4), equation (4) can be rewritten as

$\mathrm{T} \dot{\mathrm{FP}} \mathrm{it}_{\mathrm{it}}=\mathrm{TP}_{\mathrm{it}-} \mathrm{du} \mathrm{u}_{\mathrm{it}} / \mathrm{dt}+\sum_{j}\left(\boldsymbol{E}_{j}-\mathrm{S}_{\mathrm{j}}\right) \dot{\mathrm{x}}_{\mathrm{jt}}=\mathrm{TP}_{\mathrm{it}-} \mathrm{du} \mathrm{u}_{\mathrm{it}} / \mathrm{dt}+(\mathrm{RTS}-1) \sum_{j} \lambda_{\mathrm{j}} \dot{\mathrm{x}}_{\mathrm{jt}}+$

$\sum_{j}\left(\lambda_{j} S_{j}\right) \dot{x}_{j t}$

where RTS $=\sum_{j} \varepsilon_{j}$ denotes the measurement of returns to scale (RTS) and $\lambda_{j}=\varepsilon_{j} /$ RTS. The last component in equation

measures inefficiency in resource allocation resulting from the deviations of input prices from the value of their marginal product. Thus, in equation (5), TFP growth can be decomposed into TP, measures shift in production frontier over time, the technical efficiency change $\left(-\mathrm{du} \mathrm{it}_{\mathrm{it}} / \mathrm{dt}\right)$, measures the movement of production towards the known production frontier, scale components, $\mathrm{SC}=(\mathrm{RTS}-1) \sum_{j} \lambda_{\mathrm{j}} \dot{\mathrm{x}}_{\mathrm{jt}}$, measures the amount of benefit a production unit can derive from economies of scale through access to a larger market and the allocative efficiency change denoted by $\sum_{j}\left(\lambda_{j}-S_{j}\right) \dot{x}_{j t}$, measures deviation of an inputs' normalized output elasticity from its expenditure share (Kumbhakar \& Lovell, 2000).

\subsection{Model Specification}

We consider a time-varying stochastic production frontier, originally proposed by Aigner, Lovell and Schmidt (1977) in translog form with two inputs labour $(\mathrm{L})$ and capital $(\mathrm{K})$ as:

Lny $_{i t}=\beta_{0}+\beta_{\mathrm{L}} \ln L_{\mathrm{it}}+\beta_{\mathrm{K}} \ln \mathrm{K}_{\mathrm{it}}+\beta_{\mathrm{t}} \mathrm{t}+1 / 2 \beta_{\mathrm{LL}} \mathrm{Lit}^{2+1}+2 \beta_{\mathrm{KK}} \mathrm{K}_{\mathrm{it}}{ }^{2+1}+2 \beta_{\mathrm{tt}}{ }^{2}+\beta_{\mathrm{LK}} \ln \mathrm{L}$ ${ }_{i t} \ln K_{i t}+\beta_{\mathrm{Lt}} \mathrm{L}_{\mathrm{it}} \mathrm{t}+\beta_{\mathrm{Kt}} \mathrm{K}_{\mathrm{it}} \mathrm{t}+\mathrm{v}_{\mathrm{it}}-\mathrm{u}_{\mathrm{it}}$

where $\mathrm{y}_{\text {it }}$ is the level of output (gross value added), $\mathrm{K}$ and $\mathrm{L}$ are two primary inputs capital and labour respectively. The above specification allows for estimating both technological progress and time varying technical efficiency. The above translog parameterization of the stochastic frontier model allows for non- 
neutral technological progress (TP). Technological progress will be neutral if all $\beta$ tj's are equal to zero (Madheswaran et al., 2007).

The efficiency error, $u_{i t}$ represents production loss due to industryspecific technical inefficiency; thus it is always greater than or equal to zero $\left(\mathrm{u}_{\mathrm{i}} \geq 0\right)$, and it is assumed to be independent of the statistical error, $v_{i t}$, which is assumed to be independently and identically distributed as $\mathrm{N}(0,62 \mathrm{v})$ (Mandal \& Madheswaran, 2009). The distribution of technical inefficiency effects, $\mathrm{u}_{\mathrm{it}}$, is taken to be nonnegative truncation of the normal distribution $N\left(\mu, \sigma^{2} u\right)$, modelled, following (Battese \& Coelli, 1992; Greene, 1997) to be the product of an exponential function of time as

$\mathrm{u}_{\mathrm{it}}=\eta_{\mathrm{t}} \mathrm{u}_{\mathrm{i}}=\mathrm{u}_{\mathrm{i}} \exp (-\mathrm{\eta}[\mathrm{t}-\mathrm{T}]), \mathrm{i}=1, \ldots, \mathrm{N} ; \mathrm{t}=1, \ldots, \mathrm{T}$

Here the unknown parameter ' $\eta$ ' represents the rate of change in technical inefficiency, and the non-negative random variable $u_{i}$, is the technical inefficiency effect for the $i^{\text {th }}$ production unit in the last year of the data set. That is, the technical inefficiency effects in earlier periods are a deterministic exponential function of the inefficiency effects for the corresponding forms in the final period (i.e., $u_{i t}=u_{t}$ ), given the data for the $i^{\text {th }}$ production unit are available in the final period (Madheswaran et al., 2007). So the production unit with a positive ' $\eta$ ' is likely to improve its level of efficiency over time and vice-versa. A value of $\eta=0$ implies technical inefficiency is time invariant in nature (Mandal \& Madheswaran, 2009). Since the estimates of technical efficiency are sensitive to the choice of distributional assumption, we consider truncated normal distribution for general specifications of one-sided error $u_{i t}$, and half - normal distribution can be tested by LR test (Minh, Khanh, Minh \& Anh, 2012).

Technical efficiency of the $i^{\text {th }}$ production at time $t\left(\mathrm{TE}_{\mathrm{it}}\right)$, defined as the ratio of the actual output to the potential output determined by the production frontier, can be written as

$$
\left(\mathrm{TE}_{\mathrm{it}}\right)=\exp \left(-\mathrm{u}_{\mathrm{it}}\right)
$$

and technical efficiency change is the change in TE, and the rate of technological progress $\left(\mathrm{TP}_{\mathrm{it}}\right)$ is defined by,

$\mathrm{TP}_{\mathrm{it}}=\partial \operatorname{lnf}\left(\mathrm{x}_{\mathrm{it}}, \beta, \mathrm{t}\right) / \partial \mathrm{t}=\beta \mathrm{t}+\beta_{\mathrm{tt}} \mathrm{t}+\beta_{\mathrm{Lt}} \ln \mathrm{L}_{\mathrm{it}}+\beta_{\mathrm{kt}} \ln K_{\mathrm{it}}$ 
where $\beta \mathrm{t}$ and $\beta_{\mathrm{tt}}$ are 'Hicksian' parameters and $\beta_{\mathrm{Lt}}$ and $\beta_{\mathrm{kt}}$ are 'factor augmented' parameters (Madheswaran et al., 2007). It is noted that when technological progress is non-neutral, the change in TP will vary for different input vectors. To avoid this problem, Coeli et al. (1998) suggest that the geometric mean between the adjacent periods be used to estimate the TP component. The geometric mean between time $t^{\prime}$ and $t+1$ is defined as

$\mathrm{TP}_{\mathrm{it}}=\left[1+\partial \operatorname{lnf}\left(\mathrm{x}_{\mathrm{it},}, \beta, \mathrm{t}\right) / \partial \mathrm{t}\right]^{*}\left[1+\partial \operatorname{lnf}\left(\mathrm{x}_{\mathrm{it}+1,}, \mathrm{t}, \mathrm{t}+1\right) / \partial \mathrm{t}+1\right]^{1 / 2}-1$

So that both $\mathrm{TE}_{\mathrm{it}}$ and $\mathrm{TP}_{\mathrm{it}}$ vary over time and across the production units. The associated output elasticities of inputs labour and capital can be defined as

$\varepsilon_{\mathrm{L}}=\partial \operatorname{lnf}\left(\mathrm{x}_{\mathrm{it}}, \beta, \mathrm{t}\right) / \partial \ln \mathrm{L}_{\mathrm{it}}=\beta_{\mathrm{L}}+\beta_{\mathrm{LL}} \ln \mathrm{L}_{\mathrm{it}}+\beta_{\mathrm{LK}} \ln \mathrm{K}_{\mathrm{it}}+\beta_{\mathrm{Lt}} \mathrm{t}$

$\varepsilon_{\mathrm{K}}=\partial \operatorname{lnf}\left(\mathrm{x}_{\mathrm{it}}, \beta, \mathrm{t}\right) / \partial \ln \mathrm{K}_{\mathrm{it}}=\beta_{\mathrm{K}}+\beta_{\mathrm{KL}} \ln \mathrm{L}_{\mathrm{it}}+\beta_{\mathrm{KK}} \ln \mathrm{K}_{\mathrm{it}}+\beta_{\mathrm{K} \mathrm{t}} \mathrm{t}$

These two factor elasticities are used to estimate the returns to scale components' (RTS). The scale elasticity of output, i.e. the change in output with respect to change in scale, is given by the formula:

$\epsilon=\varepsilon_{\mathrm{L}^{+}} \varepsilon_{\mathrm{K}}$

If scale elasticity exceeds unity, then the technology exhibits increasing returns to scale (IRS); if it is equal to one, the technology obeys constant returns to scale (CRS), and if it is less than unity, the technology shows decreasing returns to scale (DRS).

\subsection{Measuring the Components of TFPG: A Simple Graphical Analyses}

The terms productivity and efficiency, have been used frequently in the literature over the last few years by a galaxy of researchers. These two terms are often used interchangeably, but this is unfortunate because they are not precisely the same things. To illustrate the distinction between these two terms, it is useful to consider a simple production process in which a single input $(x)$ is used to produce a single output (y). The line OF in Figure 2.2.1 represents a production frontier that may be used to define the relationship between the input and the output. The production frontier represents the maximum output attainable from each input level. Hence it reflects the current state of technology in the industry. Firms or industries operate either on that frontier if they 
are technically efficient or beneath the frontier if they are technically inefficient. Here in Figure 2.2.1 point A represents an inefficient point whereas points $B$ and $C$ represent efficient points. A firm operating at point $\mathrm{A}$ is inefficient because technically it could increase output to the level associated with point B without utilizing more input.

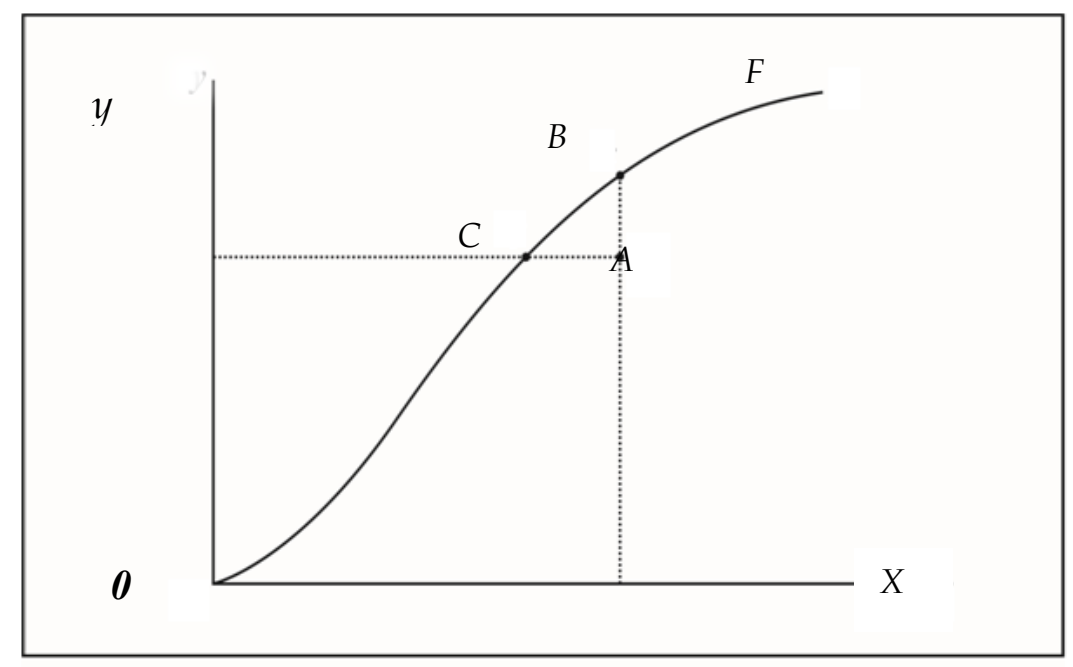

Fig 2.2.1 Production Frontiers and Technical Efficiency

To illustrate the distinction between efficiency and productivity we utilize Figure 2.2.2. In this figure, we use a ray through the origin to measure productivity at a particular data point. The slope of this ray is $y / x$ and hence provides a measure of productivity. If the firm or industry operating at point A were to move to the technically efficient point $B$, the slope of the ray would be greater, implying higher productivity at point $B$. However, by moving to point $C$, the ray from the origin is at a tangent to the production frontier and hence defines the point of maximum possible productivity. This latter movement is an example of exploiting economies of scale. The point $C$ is the point of (technically) optimum scale. Operation at any other point on the production frontier results in lower productivity. For example, at $x=X_{1}, B$ is the point of technical efficiency. The input productivity here is $\mathrm{BX}_{1} / \mathrm{OX}_{1}$. On the other hand, at $C$ that corresponds to $x=X_{m}$ (optimum) represents a technically efficient level of output and here the input productivity is $\mathrm{CX}_{\mathrm{m}} / \mathrm{OX}_{\mathrm{m}}$. Here $\mathrm{CX}_{\mathrm{m}} / \mathrm{OX}_{\mathrm{m}}>\mathrm{BX}_{1} / \mathrm{OX}_{1}$ as is evident from the fact 
$\mathrm{BD} / \mathrm{CD}<1$, since $\mathrm{B}$ is a point on the $\mathrm{CF}$ segment of the production frontier.

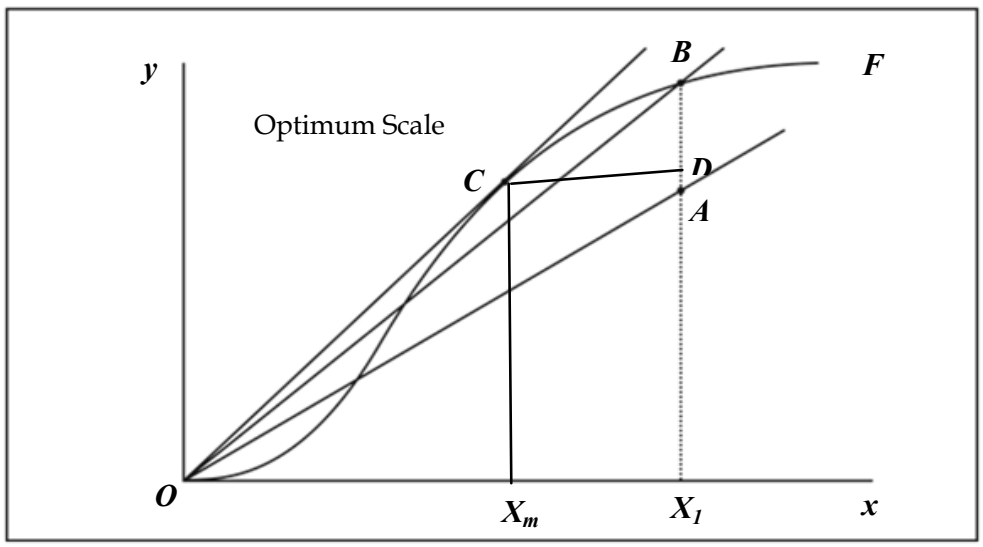

Fig 2.2.2 Productivity, Technical Efficiency and Economies of Scale

Thus we may say that a firm or an industry may be technically efficient but may still be able to improve its productivity by exploiting economies of scale. Given that changing the scale of operations of a firm or an industry can often be difficult to achieve quickly, technical efficiency and productivity can in some cases be given short-run and long-run interpretations.

The discussion above does not include a time component. When we consider productivity comparisons through time, an additional source of productivity change, called technological change, is possible. This involves advances in technology that may be represented by an upward shift in the production frontier. This is depicted in Figure 2.2.3 by the movement of the production frontier from $\mathrm{OF}_{0}$ in period 0 to $\mathrm{OF}_{1}$ in period 1 . In period 1, all firms or industries can technically produce more output for each level of input, relative to what was possible in period 0 . An example of technological change is the installation of a new boiler for a coalfired power plant that extends the plant productivity potential beyond previous limits.

When we observe that a firm or an industry has increased its productivity from one year to the next, the improvement need not 
have been from efficiency improvements alone but may have been due to technological change or the exploitation of economies of scale or from some combination of these three factors.

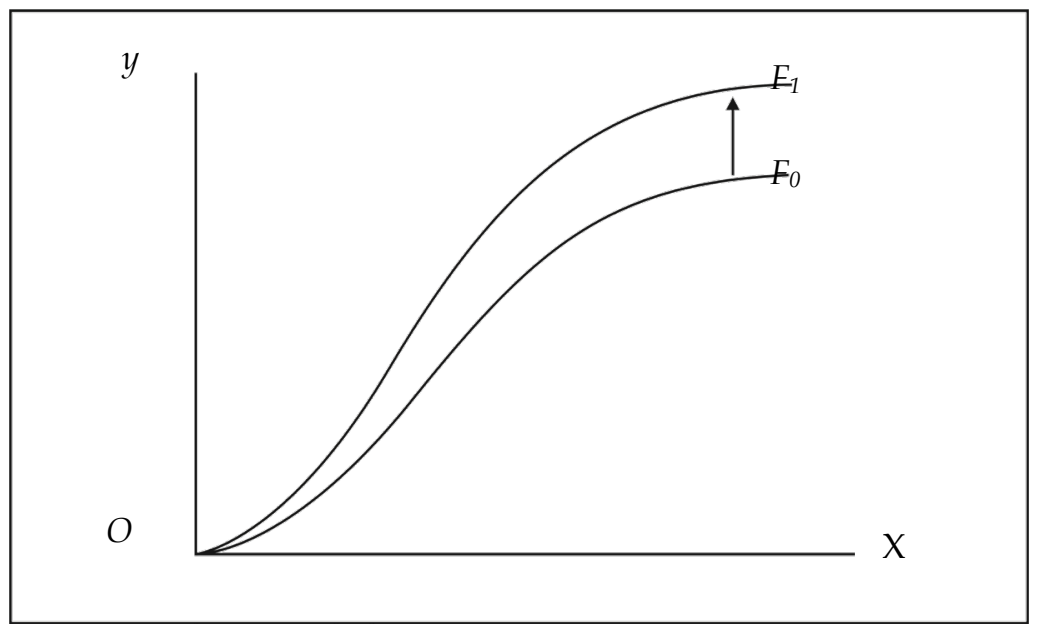

Fig 2.2.3 Technological changes between two periods

Up to this point, the discussion has focused on physical quantities and technical relationships. We have not discussed issues such as costs or profits. If the information on prices is available, and a behavioural assumption, such as cost minimization or profit maximization, is appropriate, then a performance measure can be conceived which incorporates this information. This measure refers to allocative efficiency, in addition to technical efficiency. It was Farrell (1957) who first proposed that the efficiency of a firm or an industry consists of two components: technical efficiency, which reflects the ability of a firm or an industry to obtain maximal output from a given set of inputs, and allocative efficiency, which reflects the ability of a firm or an industry to use the inputs in optimal proportions, given their respective prices and the production technology. These two measures, namely technical efficiency and allocative efficiency are then combined together to provide a measure of total economic efficiency.

Farrell illustrated the ideas of technical efficiency and allocative efficiency using a simple example involving firms or industries that use two inputs $\left(x_{1}\right.$ and $\left.x_{2}\right)$ to produce a single output $(q)$, under the assumption of constant returns to scale. Knowledge of the unit iso- 
quant of fully efficient firms or industries, represented by QQ' in Figure 2.2.4, permits the measurement of technical efficiency. If a given firm or an industry uses quantities of inputs, defined by the point $R$, to produce a unit of output, the technical inefficiency of that firm or industry could be represented by the distance RS, which is the amount by which all inputs could be proportionally reduced without a reduction in output. This is usually expressed in percentage terms by the ratio RS/OR, which represents the percentage by which all inputs need to be reduced to achieve technically efficient production. The technical efficiency (TE) of a firm or an industry is, therefore, measured by the ratio

$\mathrm{TE}=\mathrm{OS} / \mathrm{OR}$

which is equal to one minus RS/OR. It takes a value between zero and one, and, hence, provides an indicator of the degree of technical efficiency of the firm or industry. A value of one implies that the firm is fully technically efficient. For example, the point $S$ is technically efficient point because it lies on the efficient iso-quant.

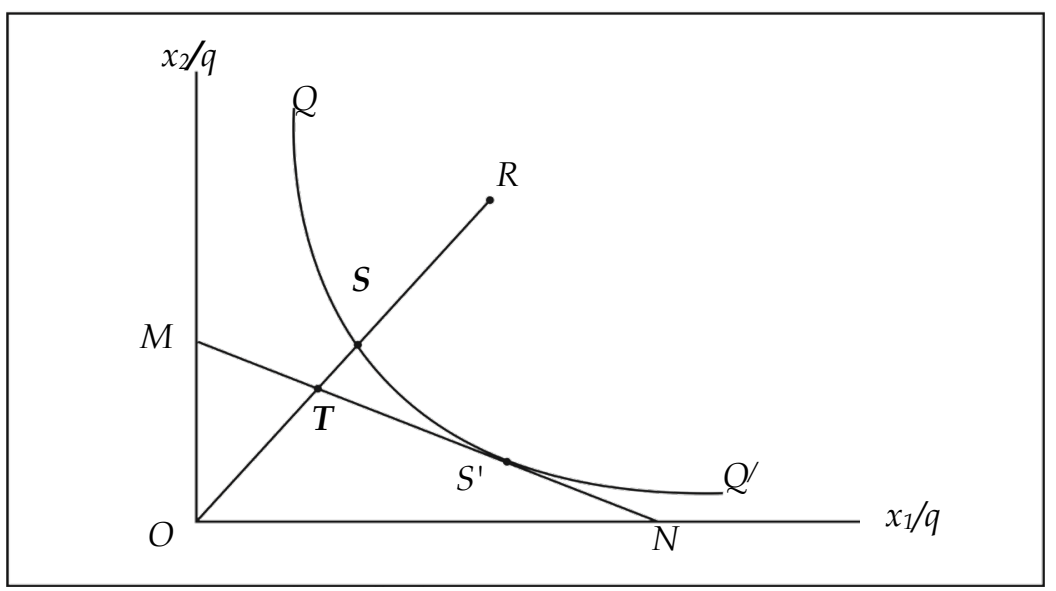

Fig 2.2.4 Technical and Allocation Efficiencies

If the input price ratio, represented by the slope of the iso-cost line, $\mathrm{MN}$, in Figure 2.2.4, is known, then allocative efficiency (AE) and technical efficiency (TE) measures can be calculated using the same iso-cost line. These are:

$\mathrm{AE}=\mathrm{OT} / \mathrm{OS}$, and 
$\mathrm{TE}=\mathrm{OS} / \mathrm{OR}$

These two equations follow from the observation that the distance ST represents the reduction in production costs that would occur if production were to occur at the allocatively (as well as technically) efficient point $S^{\prime}$ instead of at the technically efficient, but allocatively inefficient, point $S$.

\section{Data and Variables}

The study is based on panel data collected from various issues of the Annual Survey of Industries (ASI) and National Accounts Statistics (NAS) published by, Central Statistical Organization (CSO), Ministry of Statistics and Program Implementation, Government of India, New Delhi. The variables used in this exercise are output and labour and capital inputs. Deflated value added has been taken as the measure of output. The ratio of nominal and real GDP, the values of which are obtained from different volumes of NAS is treated as a deflator. The total number of persons engaged is used as the measure of labour input. Since working proprietors, owners and supervisory, managerial staff have a significant influence on the productivity of industries, the number of persons engaged is preferred to the number of workers. The price of labour is obtained by dividing the total emoluments by the total persons engaged. Net fixed capital stock at constant prices has been taken as the measure of capital input (Minh, Khanh, Minh, \& Anh, 2012). The net fixed capital stock series has been constructed from the series on the gross fixed capital formation (at constant prices) using the Perpetual Inventory Method. The annual rate of depreciation of fixed assets has been taken as 5 percent. The rental price of capital equals the ratio of interest paid and capital invested (Jorgenson \& Griliches, 1967) is treated as the price of capital.

\section{Empirical Results}

\subsection{Estimation of the Stochastic Production Frontier}

The estimation of parameters in the stochastic frontier model given by equations (20) and (21) is carried out by maximum-likelihood (ML) method, using the programme FRONTIER 4.1 (Coelli, 1996). 
Instead of directly estimating $\sigma{ }^{2} \mathrm{v}$ and $\sigma{ }^{2}$, FRONTIER 4.1 seeks to estimate $\gamma=\sigma^{2} \mathrm{u} / \sigma^{2}$ and $\sigma^{2}=\sigma{ }^{2} \mathrm{u}+\sigma{ }^{2}{ }_{\mathrm{v}}$, the results of which are presented in Table 1 . These are associated with the variances of the stochastic term in the production function, $v_{i t}$ and the inefficiency term $\mathrm{u}_{\mathrm{it}}$. The parameter $\gamma$ must lie between zero and one. If the hypothesis $\gamma=0$ is accepted, this would indicate that $\sigma^{2} \mathrm{u}$ is zero and thus the inefficiency error term, $u_{i t}$ should be removed from the model, leaving a specification with parameters that can be consistently estimated by OLS. Conversely, if the value of ' $\gamma$ ' is one, we have the full-frontier model, where the stochastic term is not present in the model. The ' $\mu$ ' parameter determines the distribution the inefficiency effects have, either a half-normal distribution or a truncated normal distribution. The ' $\eta$ ' parameter determines whether the inefficiencies are time varying or time invariant.

Table 1 shows the results of the estimation of the translog stochastic frontier production function in which the technical inefficiency effects, $u_{i t}$, have the time varying structure and follow the truncated normal distribution. The estimate of ' $\gamma$ ' which is the ratio of the variance of firm-specific performance of technical efficiency to the total variance of output is statistically significant at the 1 percent probability level. This implies that the variation in productivity performances among the industries is not due to the statistical chance factor but principally to individual technical efficiency differences (Madheswaran et al., 2007). 
Table 1: Parameter Estimates of the Stochastic Production Frontier and Technical Inefficiency Model in the Manufacturing Industries in Karnataka

\begin{tabular}{|c|c|c|}
\hline Variables & Parameters & Coefficients \\
\hline Constant & $\beta_{0}$ & $\begin{array}{l}-3.21 \\
(3.14)\end{array}$ \\
\hline $\operatorname{lnL}$ & $\mathrm{B}_{\mathrm{L}}$ & $\begin{array}{c}0.48 \\
(0.73)\end{array}$ \\
\hline $\ln K$ & $\beta_{\mathrm{K}}$ & $\begin{array}{c}0.97 * * * \\
(0.41)\end{array}$ \\
\hline $\mathrm{t}$ & $\beta_{\mathrm{t}}$ & $\begin{array}{c}0.017 \\
(0.035)\end{array}$ \\
\hline $\ln L^{2}$ & $\beta_{\mathrm{LL}}$ & $\begin{array}{c}0.021 \\
(0.048)\end{array}$ \\
\hline $\ln K^{2}$ & $\beta_{\mathrm{KK}}$ & $\begin{array}{c}-0.065 * * * \\
(0.026)\end{array}$ \\
\hline$t^{2}$ & $\beta_{\mathrm{tt}}$ & $\begin{array}{c}-0.002 * * * \\
(0.0004)\end{array}$ \\
\hline $\ln L * \ln K$ & $\beta_{\mathrm{LK}}$ & $\begin{array}{c}0.014 \\
(0.057)\end{array}$ \\
\hline $\ln L * t$ & $\beta_{\mathrm{Lt}}$ & $\begin{array}{c}-0.019 * * * \\
(0.005)\end{array}$ \\
\hline $\ln K^{*} \mathrm{t}$ & $\beta_{\mathrm{Kt}}$ & $\begin{array}{c}0.028 * * * \\
(0.005)\end{array}$ \\
\hline Sigma squared & $\sigma^{2}$ & $\begin{array}{l}0.31 * \\
(0.25)\end{array}$ \\
\hline Gamma & $\Upsilon$ & $\begin{array}{c}0.71 * * * \\
(0.24)\end{array}$ \\
\hline $\mathrm{Mu}$ & $\mu$ & $\begin{array}{c}0.24 \\
(0.59)\end{array}$ \\
\hline Eta & $\eta$ & $\begin{array}{c}0.30 \\
(0.007)\end{array}$ \\
\hline Log-Likelihood & & -90.54 \\
\hline
\end{tabular}

Standard errors are mentioned in the parenthesis

$* * *, * * \& *$ denote statistical significance at the $1 \%, 5 \%$ and $10 \%$ levels, respectively

Source: Authors' own calculation

In the above table (Table 1) it is found that the estimated value of gamma $(\gamma)$ is as high as 0.71 which implies that the organized manufacturing industries in Karnataka are operating at $71 \%$ of their potential output determined by the frontier technology (Mandal \& Madheswaran, 2009). However, a statistical test (Table 2) suggests that technical inefficiency in the organized manufacturing industries in Karnataka is absent and/or it is timeinvariant in nature, i.e., overtime changes in technical efficiency are not statistically significant in spite of a moderate changes in 60 
technological progress taking place in the 2-digit manufacturing industries in Karnataka. So it can be inferred from this result that each year or within a range of years the innovating manufacturing industries in Karnataka keep on or shifting for better technologies; however, for various reasons, such as incomplete knowledge of the best practice and other organizational factors, they are unable to follow the best practice techniques of the chosen technology. As a result, organized manufacturing industries in Karnataka fail to achieve $100 \%$ technical efficiency and the level of efficiency seems to be more or less at the same percentage level over the year. On the other hand, non-innovator industries, due to technology spillover, are also moving towards the best practice frontier i.e. they are catching up with the frontier and thereby maintaining the same distance from the frontier set by the best practice techniques. The possible reasons, for which none of the 2-digit industries in Karnataka is able to follow the best practice techniques and thereby attaining $100 \%$ efficiency, are as follows. Due to the inadequate number of domestic machinery suppliers, most of the machineries and equipments used in the 2-digit manufacturing industries are borrowed from abroad. There are certain factors that lead to poor absorption and adaptation capabilities of the borrowed technology. Firstly, poor infrastructure of the receiving companies; secondly, very limited $R \& D$ activities of the recipient companies; thirdly, inadequate technology support services of the Indian manufacturing industries and lastly, absence of any long term training programme for the local personnel. Since technical inefficiency remains absent and/or it is time invariant in nature, it has not contributed to TFP growth.

\subsection{Tests of Hypotheses of the Parameters}

In this study, various tests of hypotheses of the parameters in the frontier production function are performed using the generalized likelihood ratio test statistic, defined by

$\lambda=-2\left[\mathrm{~L}\left(\mathrm{H}_{0}\right)-\mathrm{L}\left(\mathrm{H}_{1}\right)\right]$

where $\mathrm{L}\left(\mathrm{H}_{0}\right)$ is the log-likelihood value of a restricted frontier model, as specified by a null hypothesis, $\mathrm{H}_{0}$; and $\mathrm{L}\left(\mathrm{H}_{1}\right)$ is the loglikelihood value of the general frontier model under the alternative hypothesis, $\mathrm{H}_{1}$. This test statistic has approximately a Chi-Square 
distribution (or a mixed chi-square) with degrees of freedom equal to the difference between the parameters involved in the null and alternative hypotheses. If the inefficiency effects are absent from the equation, as specified by the null hypothesis $\mathrm{H}_{0}: \gamma=0$, then the statistic $\lambda$ is approximately distributed according to a mixed chisquare distribution. Table 2 presents the test results of various null hypotheses as mentioned below:

The first likelihood test is conducted to test the null hypothesis that the translog stochastic frontier production function can be reduced to a Cobb-Douglas. The test statistic $\mathrm{H}_{0}: \beta_{\mathrm{LL}}=\beta_{\mathrm{KK}}=\beta_{\mathrm{LK}}=\beta_{\mathrm{tt}}=\beta_{\mathrm{Lt}}=\beta_{\mathrm{Kt}}=0$, as shown in Table 2, has a likelihood ratio value 35.86, which implies the rejection of the null hypothesis at $1 \%$ significance level. In other words, the translog model could not be reduced to a CobbDouglas model and is, hence, the ideal model.

Table 2: Generalized Likelihood Ratio Tests of Hypotheses for Parameters of the Stochastic Frontier Production Function in Karnataka Manufacturing

\begin{tabular}{|c|c|c|c|c|c|c|}
\hline \multirow[t]{2}{*}{ Null Hypothesis } & \multicolumn{2}{|c|}{$\begin{array}{l}\text { Log-likelihood } \\
\text { Value }\end{array}$} & \multirow{2}{*}{$\begin{array}{c}\text { Test } \\
\text { statistic } \\
\mathrm{s} \\
\lambda=-2[\mathrm{~L} \\
\left(\mathrm{H}_{0}\right)^{-} \\
\left.\mathrm{L}\left(\mathrm{H}_{1}\right)\right]\end{array}$} & \multicolumn{2}{|c|}{$\begin{array}{l}\text { Critical } \\
\text { value }\end{array}$} & \multirow{2}{*}{$\begin{array}{c}\text { Decision } \\
\\
\text { Reject } \\
\mathrm{H}_{0} / \\
\text { Accept } \\
\mathrm{H}_{0}\end{array}$} \\
\hline & $\mathrm{L}\left(\mathrm{H}_{1}\right)$ & $\mathrm{L}\left(\mathrm{H}_{0}\right)$ & & $\begin{array}{c}\text { At 1\% } \\
\text { level }\end{array}$ & $\begin{array}{c}\text { At } \\
5 \% \\
\text { level }\end{array}$ & \\
\hline $\begin{array}{l}\text { Cobb-Douglas } \\
\text { production } \\
\text { function } \\
\mathrm{H}_{0}: \beta_{\mathrm{LL}}=\beta_{\mathrm{KK}}=\beta_{\mathrm{LK}}=\beta \\
\mathrm{tt}=\beta_{\mathrm{Lt}}=\beta_{\mathrm{Kt}}=0\end{array}$ & -90.54 & -108.47 & 35.86 & 16.81 & 12.59 & $\begin{array}{c}\text { Reject } \\
\mathrm{H}_{0}\end{array}$ \\
\hline $\begin{array}{l}\text { No technological } \\
\text { change } \\
\mathrm{H}_{0} \text { : } \\
\beta_{\mathrm{t}}=\beta_{\mathrm{tt}}=\beta_{\mathrm{Lt}}=\beta_{\mathrm{Kt}}=0\end{array}$ & -90.54 & -120.60 & 60.12 & 13.28 & 9.49 & $\begin{array}{c}\text { Reject } \\
\mathrm{H}_{0}\end{array}$ \\
\hline $\begin{array}{l}\text { Neutral } \\
\text { technological } \\
\text { change } \\
\mathrm{H}_{0}: \beta_{\mathrm{Lt}}=\beta_{\mathrm{Kt}}=0\end{array}$ & -90.54 & -102.87 & 24.66 & 9.21 & 5.99 & $\begin{array}{c}\text { Reject } \\
\mathrm{H}_{0}\end{array}$ \\
\hline $\begin{array}{l}\text { No technical } \\
\text { inefficiency effects } \\
\mathrm{H}_{0}: \Upsilon=\mu=\eta=0\end{array}$ & -90.54 & -90.69 & 0.30 & 11.34 & 7.81 & $\begin{array}{c}\text { Accept } \\
\mathrm{H}_{0}\end{array}$ \\
\hline
\end{tabular}




\begin{tabular}{llllllc}
\hline $\begin{array}{l}\text { Half-normal } \\
\text { distribution of } \\
\text { technical }\end{array}$ & -90.54 & -90.58 & 0.08 & 6.63 & 3.84 & $\begin{array}{c}\text { Accept } \\
\mathrm{H}_{0}\end{array}$ \\
inefficiency & & & & & & \\
$\begin{array}{l}\mathrm{H}_{0}: \mu=0 \\
\text { Time invariant }\end{array}$ & -90.54 & -90.62 & 0.16 & 6.63 & 3.84 & $\begin{array}{c}\text { Accept } \\
\mathrm{H}_{0}\end{array}$ \\
technical & & & & & & \\
$\begin{array}{l}\text { inefficiency } \\
\mathrm{H}_{0}: \mu=0\end{array}$ & & & & & & \\
\hline
\end{tabular}

Source: Authors' own calculation

The second test we have conducted in this study consists of testing the null hypothesis that there is no technological change over time i.e. $H_{0}: \beta_{\mathrm{t}}=\beta_{\mathrm{tt}}=\beta_{\mathrm{Lt}}=\beta_{\mathrm{Kt}}=0$. The value of the test statistic as shown in Table 2 is 60.12 which is significantly larger than the critical value of 13.28 at $1 \%$ probability level. As a result, the null hypothesis of 'no technological change over time' is rejected (Mandal \& Madheswaran, 2009).

The third null-hypothesis is that technological progress is neutral i.e., $\mathrm{H}_{0}: \beta_{\mathrm{Lt}}=\beta_{\mathrm{Kt}}=0$. The value of the test statistic, in this case, becomes 24.66 which is greater than the critical value of 9.21 at $1 \%$ probability level. This indicates that the translog parameterization of the stochastic frontier model does not allow for neutral technological progress.

Fourth, null-hypothesis that technical inefficiency effects are absent $\left(\mathrm{H}_{0}: \gamma=\mu=\eta=0\right)$ is accepted. This implies that the traditional production function is an adequate representation for the organized manufacturing industries in Karnataka.

The fifth null-hypothesis, specifying that technical inefficiency effects have half-normal distribution $\left(\mathrm{H}_{0}: \mu=0\right)$ against truncated normal distribution, is accepted at $1 \%$ level of significance.

The final null-hypothesis, that technical inefficiency is timeinvariant $\left(\mathrm{H}_{0}: \eta=0\right)$ is accepted at $1 \%$ level of significance. This implies that technical inefficiency in the organized manufacturing industries in Karnataka is time-invariant in nature (Mandal \& Madheswaran, 2009). 


\subsection{Components of TFPG in the Karnataka's Manufacturing Industries}

Based on the translog production function estimates shown in Table 1 we have obtained the following measures: rates of technological progress (TP), economic scale effects (SC) and allocative efficiency effects (AEC). These measures are then added to obtain the total factor productivity growth (TFPG) [Table 6]. Because the translog specification is used, the performance of these measures varies depending on industries and years. The rates of technological progress (TP) [Table 3] in most of the 2-digit industries are positive and very high and they are found to be the major contributor to total factor productivity growth (TFPG). Technical efficiency effects of the same, however, remain absent as statistical tests suggest. The scale effects (Table 4), which measure the effect of input changes on output growth, will be zero if RTS is constant; it will be greater (less) than zero if RTS is increasing or decreasing (assuming positive input growth) (Kim \& Han, 2001). It can be seen from Table 4 that the contribution of scale effect to TFPG in most of the 2-digit manufacturing industries as well as total manufacturing industry in Karnataka are very low or even negative in most of the cases. It may be due to a larger per-unit cost of production. It can, therefore, be said that the 2-digit manufacturing industries in Karnataka have not been benefitted from economies of scale (Mandal \& Madheswaran, 2009). Allocation efficiency components (AEC) [Table 5] in most of the industries are also found to be very low or negative with high values during the entire study period. This implies that deregulation in the 2-digit manufacturing industries in Karnataka and in total manufacturing of the state has increased price distortions. This may be due to the fact that factor inputs may have been paid below their marginal products, i.e., input elasticities deviate from factor shares. 
Prasanta Kumar Roy et al. Components of Total Factor Productivity

Table 3: Average Annual Rates of Technological Progress (TP) in the 2Digit Manufacturing Industries in Karnataka

\begin{tabular}{|c|c|c|c|c|c|}
\hline $\mathrm{I} / \mathrm{P}$ & $\begin{array}{l}\text { 1981-82 } \\
\text { to } \\
2010-11 \\
\text { (Entire } \\
\text { Study } \\
\text { Period) }\end{array}$ & $\begin{array}{c}1981-82 \\
\text { to } \\
\text { 1990-91 } \\
\text { (Pre-reform } \\
\text { Period) }\end{array}$ & $\begin{array}{l}\text { 1991-92 } \\
\text { to } \\
\text { 2010-11 } \\
\text { (Post- } \\
\text { reform } \\
\text { Period) }\end{array}$ & $\begin{array}{l}\text { 1991-92 } \\
\text { to } \\
2000-01 \\
\text { (Post- } \\
\text { reform } \\
\text { Period- } \\
\text { Decade 1) }\end{array}$ & $\begin{array}{c}\text { 2001-02 } \\
\text { To } \\
\text { 2010-11 } \\
\text { (Post- } \\
\text { reform } \\
\text { Period- } \\
\text { Decade-2) }\end{array}$ \\
\hline $20-22$ & 3.83 & 5.33 & 3.07 & 3.76 & 2.38 \\
\hline $23-26$ & 1.49 & 4.08 & 0.19 & 1.51 & -1.13 \\
\hline 27 & -0.56 & 1.48 & -1.57 & -0.97 & -2.18 \\
\hline 28 & 4.83 & 8.05 & 3.23 & 4.38 & 2.07 \\
\hline 30 & 4.69 & 6.71 & 3.69 & 4.32 & 3.05 \\
\hline 31 & 6.00 & 6.54 & 5.73 & 6.09 & 5.38 \\
\hline 32 & 5.47 & 7.38 & 4.51 & 5.86 & 3.16 \\
\hline 33 & 6.51 & 6.06 & 6.74 & 6.67 & 6.80 \\
\hline $34-36$ & 4.71 & 6.78 & 3.68 & 4.73 & 2.64 \\
\hline 37 & 3.68 & 5.39 & 2.83 & 3.40 & 2.27 \\
\hline Total & 6.97 & 8.85 & 6.02 & 7.01 & 5.04 \\
\hline
\end{tabular}

Source: Authors' own calculation; I/P-Industries/Periods

Table 4: Average Annual Rates of Scale Effect (SC) in the 2-Digit Manufacturing Industries in Karnataka

\begin{tabular}{|c|c|c|c|c|c|}
\hline $\mathrm{I} / \mathrm{P}$ & $\begin{array}{c}1981-82 \\
\text { to } \\
2010-11 \\
\text { (Entire } \\
\text { Study } \\
\text { Period) }\end{array}$ & $\begin{array}{c}1981-82 \\
\text { to } \\
\text { 1990-91 } \\
\text { (Pre- } \\
\text { reform } \\
\text { Period) }\end{array}$ & $\begin{array}{c}1991-92 \\
\text { to } \\
2010-11 \\
\text { (Post- } \\
\text { reform } \\
\text { Period) }\end{array}$ & $\begin{array}{c}1991-92 \\
\text { to } \\
2000-01 \\
\text { (Post- } \\
\text { reform } \\
\text { Period- } \\
\text { Decade 1) }\end{array}$ & $\begin{array}{c}\text { 2001-02 } \\
\text { to } \\
2010-11 \\
\text { (Post- } \\
\text { reform } \\
\text { Period- } \\
\text { Decade-2) }\end{array}$ \\
\hline $20-22$ & 0 & -0.17 & 0.09 & 0.09 & 0.08 \\
\hline $23-26$ & 0.59 & 0.15 & 0.80 & 0.94 & 0.67 \\
\hline 27 & 0.39 & -1.46 & 1.31 & 1.78 & 0.84 \\
\hline 28 & -0.03 & -0.09 & 0 & -0.36 & 0.36 \\
\hline 30 & 0.04 & 0.35 & -0.12 & 0.05 & -0.29 \\
\hline 31 & -0.49 & 0.07 & -0.76 & -1.24 & -0.28 \\
\hline 32 & -0.25 & -0.04 & -0.35 & -0.65 & -0.06 \\
\hline 33 & -0.15 & -0.16 & -0.15 & 0.67 & -0.96 \\
\hline $34-36$ & -0.14 & -0.14 & -0.14 & -0.18 & -0.10 \\
\hline 37 & 0.20 & 0.11 & 0.25 & 0.26 & 0.23 \\
\hline Total & -0.17 & 0.09 & -0.30 & 0.12 & -0.71 \\
\hline
\end{tabular}

Source: Authors' own calculation; I/P-Industries/Periods 
Table 5: Average Annual Rates of Allocation Efficiency Effect (AEC) in the 2-digit Manufacturing Industries in Karnataka

\begin{tabular}{|c|c|c|c|c|c|}
\hline $\mathrm{I} / \mathrm{P}$ & $\begin{array}{c}\text { 1981-82 } \\
\text { to } \\
2010-11 \\
\text { (Entire } \\
\text { Study } \\
\text { Period) }\end{array}$ & $\begin{array}{c}\text { 1981-82 } \\
\text { To } \\
\text { 1990-91 } \\
\text { (Pre-reform } \\
\text { Period) }\end{array}$ & $\begin{array}{c}1991-92 \\
\text { To } \\
2010-11 \\
\text { (Post- } \\
\text { reform } \\
\text { Period) }\end{array}$ & $\begin{array}{c}\text { 1991-92 } \\
\text { to } \\
\text { 2000-01 } \\
\text { (Post- } \\
\text { reform } \\
\text { Period- } \\
\text { Decade 1) }\end{array}$ & $\begin{array}{c}\text { 2001-02 } \\
\text { to } \\
\text { 2010-11 } \\
\text { (Post- } \\
\text { reform } \\
\text { Period- } \\
\text { Decade-2) }\end{array}$ \\
\hline $20-22$ & -1.3 & -2.04 & -0.93 & -1.46 & -0.41 \\
\hline $23-26$ & -0.28 & -0.92 & 0.04 & -0.14 & 0.23 \\
\hline 27 & 1.74 & -0.17 & 2.69 & 4.09 & 1.29 \\
\hline 28 & -0.81 & -2.40 & -0.01 & -2.14 & 2.12 \\
\hline 30 & -0.76 & -1.25 & -0.51 & -1.63 & 0.60 \\
\hline 31 & -5.31 & -0.01 & -7.96 & -17.89 & 1.97 \\
\hline 32 & -3.31 & -3.84 & -3.05 & -5.75 & -0.34 \\
\hline 33 & -4.34 & 0.08 & -6.55 & -12.18 & -0.91 \\
\hline $34-36$ & -1.05 & -1.48 & -0.83 & -0.66 & -1.00 \\
\hline 37 & 0.61 & 0.29 & 0.77 & 0.90 & 0.65 \\
\hline Total & -2.66 & -2.20 & -2.89 & -4.86 & -0.93 \\
\hline
\end{tabular}

Source: Authors' own calculation; I/P-Industries/Periods

Table 6: Average Annual Rates of Total Factor Productivity Growth (TFPG) in the 2-Digit Manufacturing Industries in Karnataka

\begin{tabular}{|c|c|c|c|c|c|}
\hline $\mathrm{I} / \mathrm{P}$ & $\begin{array}{l}\text { 1981-82 } \\
\text { to } \\
2010-11 \\
\text { (Entire } \\
\text { Study } \\
\text { Period) }\end{array}$ & $\begin{array}{c}1981-82 \\
\text { to } \\
1990-91 \\
\text { (Pre- } \\
\text { reform } \\
\text { Period) }\end{array}$ & $\begin{array}{l}\text { 1991-92 } \\
\text { to } \\
2010-11 \\
\text { (Post- } \\
\text { reform } \\
\text { Period) }\end{array}$ & $\begin{array}{l}\text { 1991-92 } \\
\text { to } \\
2000-01 \\
\text { (Post- } \\
\text { reform } \\
\text { Period- } \\
\text { Decade 1) }\end{array}$ & $\begin{array}{c}\text { 2001-02 } \\
\text { To } \\
\text { 2010-11 } \\
\text { (Post-reform } \\
\text { Period- } \\
\text { Decade-2) }\end{array}$ \\
\hline $20-22$ & 2.53 & 3.12 & 2.23 & 2.39 & 2.05 \\
\hline $23-26$ & 1.80 & 3.31 & 1.03 & 2.31 & -0.23 \\
\hline 27 & 1.57 & -0.15 & 2.43 & 4.90 & -0.05 \\
\hline 28 & 3.99 & 5.56 & 3.22 & 1.88 & 4.55 \\
\hline 30 & 3.97 & 5.81 & 3.06 & 2.74 & 3.36 \\
\hline 31 & 0.20 & 6.60 & -2.99 & -13.04 & 7.07 \\
\hline 32 & 1.91 & 3.50 & 1.11 & -0.54 & 2.76 \\
\hline 33 & 2.02 & 5.98 & 0.04 & -4.84 & 4.93 \\
\hline $34-36$ & 3.52 & 5.16 & 2.71 & 3.89 & 1.54 \\
\hline 37 & 4.49 & 5.79 & 3.85 & 4.56 & 3.15 \\
\hline Total & 4.14 & 6.74 & 2.83 & 2.27 & 3.40 \\
\hline
\end{tabular}

Source: Authors' own calculation; I/P-Industries/Periods 
It is found that TFPG (Table 6) in almost all the 2-digit industries in Karnataka declined during the post-reform period and the decline in TFPG of the said industries in Karnataka is mainly responsible for the decline in TP of the same during that period. Further, the combined effect of both the scale effect and allocation efficiency effect becomes very low or they have become negative in most of the industries. It is to be noted that the estimates of TFPG become maximum in case of the manufacture of transport equipments (37) during the entire study period as well as during the post-reform period (1981-82 to 2010-11 \& 1991-92 to 2010-11). Here the estimates of higher TFPG in this industry are probably due to higher growth rates of technological progress as well as positive values of both the scale effect and allocation efficiency effect during the entire study period, pre-reform period as well as during the post-reform period. However, the rates of TFPG become negative in the case of wood and wood products (27) during the pre-reform period and in the case of petroleum and coal products (31) during the post-reform period instead of positive and high rates of TP of them during the aforementioned periods.

\section{Conclusion}

The paper examines the sources of TFPG of the 2-digit manufacturing industries in Karnataka during the period from 1981-82 to 2010-11, during the entire period, pre-reform period (1981-82 to 1990-91), post-reform period (1991-92 to 2010-11) and also during two different decades of the post-reform period (199091 to 2000-01 \& 2001-02 to 2010-11) using stochastic frontier approach. The methodology involves decomposition of the sources of TFPG into four components, i.e., technological progress, technical efficiency change, economic scale effect, and allocation efficiency effect.

The main findings of the study are that during the periods under study, technological progress has been the main driving force of productivity growth in the organized manufacturing industries in Karnataka and the decline in productivity growth of the organized manufacturing industries in Karnataka is mainly due to decline in $\mathrm{TP}$ of the same during that period. The scale effects and the allocation efficiency effects in almost all the 2-digit industries in 
Karnataka have been found to be very low or even negative with very high values. The lower values of the combined effect of scale change and allocation efficiency change are also responsible for the decline in TFPG of the same during that period. Kaliranjan and Balasubramanya (2009) and Sharmila and Hosamane (2014) also show that TFPG of the manufacturing industries in Karnataka has declined during the post-reform period.

The Government of Karnataka has always had a clear emphasis on its policies towards the growth of industrial productivity of the state. The main policy instruments of the state were the same as that of the central government, that is, deregulation and delicensing of the industries, incentives, and concessions to potential industrialists in India and abroad, and promotional and developmental work. However, more emphasis should be given on incentives and concessions. It indicates that more importance should be given on the development of infrastructure in the state, with the objective of attracting more private investment in infrastructure such as roads, power plants, ports jetties, etc (Hirway, 2000). This policy will be helpful for attracting more foreign direct investments in the state's industries particularly in the large and medium industries and it should be embodied with labour intensive technology as India is a huge labour surplus country. Policies should also be geared to improve efficiency and utilize resources optimally. Human capital is scarce in India, and it will take a relatively long time for individuals to be educated and trained. Thus, continuous investment in education and training is necessary. Mobility of human capital can facilitate knowledge spillovers across different states in India, and encouraging international flows of talents might also be necessary. However, brain drain should be stopped altogether. It will be interesting for future analysis, for example, to consider the technological progress and efficiency changes among the industries in different states in India. In this context, governments should take some policy initiatives to improve the production efficiency of the organized manufacturing industries. Once efficiency increases, it will enhance competitiveness by realizing the potential output growth of the industries. 
Prasanta Kumar Roy et al. Components of Total Factor Productivity

\section{Appendix}

Table 6

Concordance between NIC'87, NIC'98 \& NIC'04 and NIC'08 of 2-Digit Manufacturing Industries

\begin{tabular}{|c|c|c|c|}
\hline Industries & $\begin{array}{l}\text { NIC'87 } \\
\text { code }\end{array}$ & $\begin{array}{c}\text { NIC'98 \& } \\
\text { NIC'04 code }\end{array}$ & NIC 2008 code \\
\hline Food, Beverages & & $151+152+153+$ & $101+102+103+104$ \\
\hline and Tobacco & $20-22$ & $154+155$ & $+105+106+107+108$ \\
\hline Products & & +160 & $+110+120$ \\
\hline $\begin{array}{l}\text { Textile and } \\
\text { Textile Products }\end{array}$ & $23+24+25+26$ & $171+172+173+181$ & $131+139+141+143$ \\
\hline $\begin{array}{l}\text { Wood and Wood } \\
\text { Products }\end{array}$ & 27 & $20+361$ & $16+310$ \\
\hline $\begin{array}{l}\text { Paper and Paper } \\
\text { Products }\end{array}$ & 28 & $21+22$ & $17+18$ \\
\hline $\begin{array}{l}\text { Chemicals and } \\
\text { Chemical }\end{array}$ & 30 & 24 & $20+21$ \\
\hline $\begin{array}{l}\text { Products } \\
\text { Rubber, }\end{array}$ & & & \\
\hline $\begin{array}{l}\text { Petroleum and } \\
\text { Coal Products }\end{array}$ & 31 & $23+25$ & $19+22$ \\
\hline $\begin{array}{l}\text { Non-Metallic } \\
\text { Mineral Products }\end{array}$ & 32 & 26 & 23 \\
\hline $\begin{array}{l}\text { Basic Metals and } \\
\text { Alloys Industries }\end{array}$ & 33 & $271+272+273+371$ & $241+242+243$ \\
\hline $\begin{array}{l}\text { Metal Products } \\
\text { and Machinery } \\
\text { Equipments }\end{array}$ & $34+35+36$ & $28+29+30+31+32$ & $25+26+27+28$ \\
\hline $\begin{array}{l}\text { Transport } \\
\text { Equipments } \\
\text { Total } \\
\text { Manufacturing }\end{array}$ & 37 & $34+35$ & $29+30$ \\
\hline
\end{tabular}

Source: Article by Pulapri Balakrishnan \& M Suresh Babu published in EPW Sept. 20, 2003, Page 4004

\section{References}

Aigner, D., Lovell, C. K., \& Schmidt, P. (1977). Formulation and estimation of stochastic frontier production function models. Journal of Econometrics, 6(1), 21-37. 
Battese, G. E., \& Coelli, T. J. (1988). Prediction of firm level technical inefficiencies with a generalized frontier production function. Journal of Econometrics, 38, 387-399.

Battese, G. E., \& Coelli, T. J. (1992). Frontier production functions, technical efficiency and panel data: with application to paddy farmers in India. Journal of Productivity Analysis, 3(1-2), 153-169.

Battese, G. E., \& Coelli. T. J. (1995). A model for technical inefficiency effects in a stochastic frontier production for panel data. Empirical Economics, 20(2), 325-332.

Bauer, P. W. (1990). Recent developments in the econometric estimation of frontiers. Journal of Econometrics, 46(1-2), 39-56.

Chiona, S., Kalinda, T., \& Tembo, G. (2014). Stochastic frontier analysis of the technical efficiency of smallholder maize farmers in Central Province, Zambia. Journal of Agricultural Science, 6(10), 108-118.

Coelli, T. J., Prasada Rao, D. S., \& Battese, G. E. (1998). An introduction to efficiency and productivity analysis. Kluwer Academic Publisher. USA: Boston.

Coelli, T. J. (1996). A guide to FRONTIER version 4.1: A computer program for stochastic frontier production and cost function estimation, 7, 1-33. CEPA Working Paper.

Coelli, T. J., Rao, D. S. P., O'Donnell, C. J., \& Battese, G. E. (2005). An introduction to efficiency and productivity analysis. Springer Science \& Business Media.

Cornwell, C., Schmidt, P., \& Sickles, R. C. (1990). Production frontier with cross-sectional and time-series variation in efficiency levels. Journal of Econometrics, 46(1/2), 185-200.

CSO. (2007). National account statistics. New Delhi: Government of India.

Denny, M., Fuss, M., Everson, C., \& Waverman, L. (1981). Estimating the effects of diffusion of technological innovations in telecommunications: The production structure of Bell Canada. Canadian Journal of Economics, 24-43.

Domazlicky, B. R., \& Weber, W. L. (1998). Determinants of total factor productivity, technological change and efficiency differentials among states, 1977-86. Review of Regional Studies, 28(2), 19-33.

Fecher, F., \& Perelman, S. (1992). Productivity growth and technical efficiency in OECD industrial activities. Industrial Efficiency in Six Nations, 459-488

Forsund, F. R., Lovell, C. A. K., \& Schmidt, P. (1980). A survey of frontier productions and of their relationship to efficiency measurement. Journal of Econometrics, 13(1), 5-25.

Goldsmith, R. W. (1951). A perpetual inventory of national wealth. In Studies in Income and Wealth, Volume 14, 5-73. NBER. 
Gounder, R., \& Xayayong, V. (2004). A decomposition of total factor productivity growth in New Zealand's manufacturing industries: A stochastic frontier approach. Department of Science and International Economics Massey University Palmerston North New Zealand.

Green, W. H. (1997). Frontier production functions. In M. H. Pesaran \& P. Schmidt (Eds.), Handbook of applied econometrics, vol. 2, pp. 81-166. Oxford: Blackwell Publishers Ltd.

Greene. W. (2005). Reconsidering heterogeneity in panel data estimators of the stochastic frontier model. Journal of Econometrics, 126(2), 269303.

Hamit-Haggar, M. (2009). Total factor productivity growth, technological progress and efficiency changes: empirical evidence from Canadian manufacturing industries. Department of Economics, University of Ottawa, Canada, Working Paper.

Hirway. (2000). Dynamics of development in Gujarat: Some issues. Economic and Political Weekly, 35(35).

Jorgenson, D., \& Griliches, Z. (1967). The explanation of productivity change. The Review of Economic Studies, 34(99), 249-280.

Kaliranjan, K., \& Balasubrahmanya, M. H. (2009). An analysis of the performance of manufacturing industries in Karnataka state. The Indian Economic Journal, 56(4), 95-111.

Kim, S., \& Han, G. (2001). A decomposition of total factor productivity growth in Korean manufacturing industries: A stochastic frontier approach. Journal of Productivity Analysis, 16(3), 269-281.

Korres, G. M., \& Polychronopoulos, G. (2008). Productivity and regional growth in Europe. International Conference on Applied Economics., 537546.

Kumbhakar, S. C., Wang, H. J., \& Horncastle, A. P. (2015). A practitioner's guide to stochastic frontier analysis using stata. USA: Cambridge University Press.

Kumbhakar, S. C. (1990). Production frontiers, panel data and timevarying technical inefficiency. Journal of Econometrics, 46(1/2), 201-212.

Kumbhakar, S. C., \& Knox Lovell, C. A. (2000). Stochastic frontier analysis, 279-309. U.K.: Cambridge University Press.

Kumbhakar, S. C., Ghosh, S., \& McGuckin, J. T. (1991). A generalized production frontier approach for estimating determinants of efficiency in U.S. dairy farms. Journal of Business and Economic Statistics, 9(3), 279286.

Madheswaran, S., Liao, H., \& Rath, B. N. (2007). Productivity growth of Indian manufacturing sector: Panel estimation of stochastic production frontier and technical efficiency. The Journal of Developing Areas, 40(2). 
Mandal, S. K., \& Madheswaran, S. (2009). Technological progress, scale effect and total factor productivity growth in Indian cement industry: Panel estimation of stochastic production frontier. The Institute for Social and Economic Change, Bangalore. Working Paper.

Meeusen, W., \& Van den Broeck, J. (1977). Efficiency estimation form Cobb-Douglas production function with composed error. International Economic Review, 18(2), 435-444.

Minh, N. K., Khanh, P. V., Minh, N. T., \& Anh, N. T. P. (2012). Productivity growth, technological progress and efficiency change in Vietnamese manufacturing industries: A stochastic frontier approach. Open Journal of Statistics, 2, 224-235.

Nishimizu, M, \& Page, Jr., J. M. (1982). Total factor productivity growth, technological progress and technical efficiency change: Dimensions of productivity change in Yugoslavia, 1965-78. Economic Journal, 92(368), 920-936.

Norsworthy, J. R., \& Jang, S. L. (1992). Empirical measurement and analysis of productivity and technological change. Amsterdam: Elsevier Science Publisher.

OECD. (2001). Productivity and firm dynamics: Evidence from micro data. Economic Outlook, 69, 209-233.

Pit, M. M., \& Lee, L. F. (1981). The measurement and sources of technical inefficiency in the Indonesian weaving industry. Journal of Development Economics, 9(1), 43-64.

Reifschneider, D., \& Stevenson, R. (1991). Systematic departures from the frontier: A framework for the analysis of firm inefficiency. International Economic Review, 32(3), 715-723.

Reserve Bank of India, (2004). Report on Currency and Finance, 2002-03. Mumbai.

Roy, P. K., Das, P. S. (2018). Productivity growth decomposition in the manufacturing industries of food, beverages and tobacco products in India: A stochastic frontier approach. Arthashastra: Indian Journal of Economics \& Research, 7(1), 37-57.

Roy, P. K., Das, P. S., \& Neogi, C. (2015). Interstate analysis of the decomposition of total factor productivity growth in the organized manufacturing industries in India: A stochastic frontier approach. Artha Vijnana, Gokhale Institute of Politics and Economics, 57(2), 135-160

Roy, P. K., Das, P. S., \& Pal, M. K. (2015-16), Decomposition of total factor productivity growth of the organized manufacturing industries in West Bengal: Panel estimation of stochastic production frontier. Vidyasagar University Journal of Economics, 20, 20-42.

Roy, P. K., Das, P. S., \& Pal, M. K. (2016). Productivity growth in Indian manufacturing: Panel estimation of stochastic production frontier. 
Indian Journal of Industrial Relations, Sri Ram Centre for Industrial Relations, Human Resources, Economic \& Social Development, 52(1), 71-86. Roy, P. K., Das, P. S., \& Pal, M. K. (2017). Decomposition of output and productivity growth: A panel study of 2-digit manufacturing industries in West Bengal. Artha Beekshan, Journal of Bengal Economic Association, 26(3), 40-63.

Roy, P. K., Das, P. S., \& Pal, M. K. (2017). Decomposition of output and productivity growth of the 2-digit manufacturing industries in West Bengal: A stochastic frontier approach. Rabindra Bharati University Journal of Economics, 11, 48-66.

Roy, P. K., Das, P. S., \& Pal, M. K. (2017). Decomposition of total factor productivity growth of the 2-digit manufacturing industries in West Bengal:Aa stochastic frontier approach. Arthaniti, 16(1\&2), 101-124.

Roy, P. K., Das, P. S., \& Pal, M. K. (2017). Output and productivity growth decomposition: A panel study of the total organized manufacturing of fifteen major industrialized states in India. The Indian Journal of Economics, 388.

Roy, P. K., Das, P. S., \& Pal, M. K. (2018). Output and productivity growth decomposition: A panel study of manufacturing industries in India. The Indian Journal of Industrial Relations, 53(3), 361-377.

Schmidt, P., \& Sickles, R.C. (1984). Production frontiers and panel data. Journal of Business and Economic Statistics, 2(4), 367-374.

Sharma, S. C., Sylwester, K., \& Margono, H. (2007). Decomposition of total factor productivity growth in U.S. states. Quarterly Review of Economics and Finance, 47(2), 215-241.

Sharmila, R., \& Hosamane, M. D. (2014). An empirical analysis of total factor productivity growth of manufacturing sector in Karnataka. MSRUAS Journal of Management and Commerce, 1(1), 5-8.

Solow, R. M. (1957). Technical change and the aggregate production function. The Review of Economics and Statistics, 39(3), 312-320. 